SOIL Discuss., https://doi.org/10.5194/soil-2018-13

Manuscript under review for journal SOIL

Discussion started: 4 June 2018

(c) Author(s) 2018. CC BY 4.0 License.

\title{
Phosphorus transport in lateral subsurface flow at forested hillslopes
}

\author{
Jakob Sohrt $^{1}$, Heike Puhlmann ${ }^{2}$ and Markus Weiler ${ }^{1}$
}

5

${ }^{1}$ Chair of Hydrology, Albert-Ludwigs-University of Freiburg, Friedrichstraße 39, 79098 Freiburg, Germany

${ }^{2}$ Forest Research Institute of Baden-Württemberg, Wonnhaldestr. 4, 79100 Freiburg, Germany

Correspondence to: Jakob Sohrt, jakob.sohrt@posteo.de

10 Abstract. This study is concerned with the transport of Phosphorus $(\mathrm{P})$ with lateral subsurface flow in the organic layer and topsoil of three forested headwater sites in Germany. Sampling frequency was set proportional to the incident flow rate in high temporal resolution. With this approach we want to investigate intra-event dynamics of $\mathrm{P}$ transport in lateral subsurface flow to establish initial process understanding about this potentially relevant pathway of P loss in forested hillslopes. With the organic layer being an important transfer site in the P cycle of temperate forests, availability and transportability of $\mathrm{P}$ in short timescales may reveal details about the overall balance of $\mathrm{P}$ in theses ecosystems. Our results demonstrate that $\mathrm{P}$ concentrations in lateral flow are highly variable within and in between distinct flow events as well as among our study sites. To determine possible controls of the P transport we constructed multiple linear models of the $\mathrm{P}$ concentration in lateral flow as a function of site specific environmental datasets. Site affiliation was responsible for more than half of total explained variability regarding P concentration in lateral flow, followed by flow rate, electric conductivity of subsurface lateral flow

Keywords: phosphorus, transport controls, lateral flow, organic layer, temperate forest, event dynamics 
SOIL Discuss., https://doi.org/10.5194/soil-2018-13

Manuscript under review for journal SOIL

Discussion started: 4 June 2018

(c) Author(s) 2018. CC BY 4.0 License.

\section{Introduction}

25 Phosphorus is essential for all life and its availability often limits primary productivity of ecosystems (Elser et al. 2007; Elser et al. 2000). Original P input into unfertilized, terrestrial ecosystems is mainly caused by weathering of bedrock material and likely to a lesser degree by atmospheric deposition (Buendia et al. 2010; Mahowald et al. 2008; Newman 1995; Tipping et al. 2014) Both fluxes of P into the ecosystem are generally orders of magnitudes smaller than P fluxes within the ecosystem, like plant uptake and litter fall (Cole and Rapp 1981; Gosz et al. 1972; Yanai 1992). This necessitates the existence of efficient mechanisms to reduce losses of $\mathrm{P}$ from the ecosystem (Hättenschwiler and Vitousek 2000; Lang et al. 2016; Wood et al. 1984), which are thought to occur mostly through solutes and suspended particles in soil water seepage, groundwater and eventually stream flow (Cole and Rapp 1981).

The organic layer plays a key role in the P cycle of temperate forest ecosystems: It receives large P inputs through dead biomass from above and below ground sources as well as from atmospheric deposition, which are then available for biotic turnover. P can be removed from the organic layer again by biological uptake or leaching with vertical or lateral water flow (Attiwill and Adams 1993; Clark et al. 2001; Cole and Rapp 1981; Eckstein et al. 1999; Fisk and Fahey 2001; Gaudinski et al. 2000; O’neill and DeAngelis 1981; Yanai 1992).

In situations where $\mathrm{P}$ availability may limit ecosystem productivity, organisms are expected to compete for available $\mathrm{P}$ and thus keep its concentrations in soil solution, the point of microbial- and plant uptake, at a low level (Björkman and

40 Lundeberg 1971; Goldberg 1990; Turner et al. 2013). Additionally, ionic P is effectively immobilized on the surfaces of biological and mineral particles, further reducing the potential of $\mathrm{P}$ loss through soil water flow. Particulate forms of $\mathrm{P}$ may be retained in the soil through mechanical filtering, but their relative depletion with soil depth has been demonstrated to be lower than for ionic P (Compton and Cole 1998; Fitzhugh et al. 2001; Ilg et al. 2009; Johnson et al. 2016; Kaiser et al. 2001a,b; Qualls et al. 2002). Through these processes, the concentration of $P$ in groundwater and streamflow of undisturbed forested headwaters is often orders of magnitudes lower than in streamflow generated at fertilized sites, illustrating the tightness of forested headwaters P cycle (Beaulac and Reckhow 1982; Dillon and Kirchner 1975; Reckhow et al. 1980; Vuorenmaa et al. 2002).

Lateral subsurface flow is an important process of runoff generation in forest soils, due to the regular occurrence of preferential flowpaths and the uneven distribution of precipitation input to the organic layer (Bachmair et al. 2012;

50 Schwärzel et al. 2012). Preferential flowpaths may develop along roots and animal burrows which are a common feature of forest soils, or through soil physical processes like freezing, thawing and changes in soil water content (Aubertin 1971; Beven and Germann 1982; Beven and Germann 2013). The forest canopy is effective in partitioning incoming precipitation, creating areas of higher water input directly at the tree base through stemflow, and at arbitrary positions where throughfall may be accumulated through temporal interception and channeling along canopy elements (Keim, Skaugset \& Weiler 2005; Schwärzel et al. 2012). Other than P transport with water flow through the soil matrix, lateral subsurface flow can effectively transport particulate matter (Bachmair et al. 2009; Cox et al. 2000; Fuchs et al. 2009; Jardine et al. 1990; Vinther et al. 1999). This is highly relevant for the transport of P, as P in the soil water is predominantly found in particulate forms (Timmons, Verry, Burwell \& Holt 1977; Cox et al. 2000; Kaiser et al. 2001b; Qualls et al. 2002; Kaiser \& Guggenberger 2003; Fuchs et al. 2009; Bol et al. 2016; Julich, Julich \& Feger 2016;

60 Missong et al. 2016). Additionally, the higher flow velocity and reduced contact time between soil material and water in preferential flowpaths reduces retention of transported P on soil particles (Jarvis 2007). The biogeochemical attributes of preferential flowpaths may differ extensively from those of the bulk soil (Aubertin 1971). Earthworm burrows are coated with a substance that is much less effective in retaining inorganic P forms than the bulk soil, and flowpaths along roots - living or dead - are hot-spots of microbial activity (Bundt et al. 2001; Jensen, Hansen \& Magid 2002). In 
SOIL Discuss., https://doi.org/10.5194/soil-2018-13

Manuscript under review for journal SOIL

Discussion started: 4 June 2018

(c) Author(s) 2018. CC BY 4.0 License.

comparison to other forest biomass compartments, microbes - especially bacteria - have a high $\mathrm{P}$ content and high turnover rate. During low flow velocities, they may take up P from subsurface flow, or getting dragged along at higher flow velocities (Vinther et al. 1999).

The aim of the study is to improve our understanding of the processes relevant to $\mathrm{P}$ transport via lateral flow in the organic layer, which is so far very limited. It is still unclear, to which degree $\mathrm{P}$ transport in lateral subsurface flow in the upper soil layer and organic layer is controlled by availability of transportable $\mathrm{P}$ or by the transport capacity transport in the form of lateral subsurface flow. To investigate the importance of these two fundamental processes, we sample $\mathrm{P}$ concentration in lateral subsurface flow as well as the flow rate and soil moisture, which may serve as proxies for the transport capacity and small scale hydrological connectivity. We assume, that availability and possible buildup of transportable $\mathrm{P}$ is controlled by biological activity resulting in the breakdown of organic layer material, for which air temperature, soil moisture and the period between rainfall events are used as proxies. To test, whether findings are significant beyond the scope a single site, the experiment is repeated at three sites.

\section{Methods}

Sampling took place at three forested hillslope sites in Germany: Mitterfels (MIT) in Bavaria, Vessertal (VES) in

Thuringia and Conventwald (CON) in Baden-Württemberg. The sites were selected for similar vegetation but differences in mineral soil P content within the framework of the SPP 1685 program on forest phosphorus nutrition (Lang et al. 2016).

All three sites are old-growth european beech (Fagus sylvatica) forests with little management in the last decades and sparse or absent undergrowth aside from beech saplings. Sample collection was carried out from March to November 2015 with the construction of the field installations taking place the year before. Recent studies are available that broach issues of P cycling at the same sites as our study with regards to microbes (Bergkemper et al. 2016a,b; Bünemann, Augstburger \& Frossard 2016; Zederer, Talkner, Spohn \& Joergensen 2017), soil P species (Missong et al. 2016; Prietzel, Klysubun \& Werner 2016; Lang et al. 2017), hydrology (Julich et al. 2016; Julich et al. 2017), plants (Netzer, Schmid, Herschbach \& Rennenberg 2017) and the effect of liming and nitrogen input (Holzmann et al. 2016).

90

$$
\text { -- Table } 1 \text {-- }
$$

The capacity of lateral subsurface flow in forest soils to transport large amounts of $\mathrm{P}$ in short timescales has been demonstrated by field studies, though the reasons for high spatio-temporal variations in lateral flow $\mathrm{P}$ concentrations are so far not explicitly clear. (Cox et al. 2000; Fuchs et al. 2009; Timmons et al. 1977). Lateral subsurface flow events show a high temporal variability in terms of flow rate (Bachmair and Weiler 2012a; Bachmair et al. 2009) and chemical composition (Burns et al. 1998; Hill et al. 1999; Newman et al. 1998), and may thus not be accurately represented by grab sampling, bulk sampling or suction-based sampling of soil water. To overcome these limitations, we sample free draining, unfiltered lateral flow in the organic layer with a temporal resolution from minutes to hours, to match temporal dynamics of other parameters related to lateral flow such as precipitation input and changes in soil moisture.

At each hill slope site, a $10 \mathrm{~m}$ wide trench was dug along the local contour line. Lateral flow from the organic layer, which varied in thickness from 10 to $25 \mathrm{~cm}$, is captured in this trench and channeled to a sampling point. This is archived by placing a drainage mat to the up-slope wall of the trench, which is connected to a pipe at the bottom. After the installation of the drainage equipment, the trench was filled in again. A more detailed description of the building 
SOIL Discuss., https://doi.org/10.5194/soil-2018-13

Manuscript under review for journal SOIL

Discussion started: 4 June 2018

(c) Author(s) 2018. CC BY 4.0 License.

105 process can be found in Bachmair and Weiler (2012b). This method allows for the collection of representative and undisturbed water samples, as no significant filtering occurs. When lateral flow is captured in the trench, the water is directed to a tipping bucket with $100 \mathrm{ml}$ resolution and a $2 \mathrm{~L}$ reservoir below. The content of the reservoir is pumped to a flow through cell with a volume of $300 \mathrm{ml}$ when a pre-defined volume of lateral flow water has accumulated. In the flow through cell, electric conductivity (EC) is measured with a Decagon CTD-sensor, after which a water sample is drawn to a $100 \mathrm{ml}$ glass bottle in an enclosed autosampler. 40 samples can be drawn by one autosampler at minimum intervals of 10 minutes. The process is fully automated and all data is transmitted in near real time via the cellular network.

At the field site CON, a meteorological station is available in a distance of less then $100 \mathrm{~m}$, at the site MIT the distance to the nearest meteorological station is approximately $500 \mathrm{~m}$. At the site VES there was no meteorological station in the

115 direct vicinity and the nearest DWD station $10 \mathrm{~km}$ away was used. These meteorological stations are used as sources for time series of air temperature and precipitation. Soil moisture in the organic layer is measured in 3 locations, $2 \mathrm{~m}$ up slope of the trench installations.

The water samples were collected in the field twice a week at the site CON and every three weeks at the sites VES and MIT. Collection intervals of this length must be assumed to be too long to allow for the subsequent analysis of different

$120 \mathrm{P}$ species, as biological transformation in untreated samples will change their distribution in much shorter timescales. As a consequence, only total phosphorus of the unfiltered samples $\left(\mathrm{P}_{\text {tot }}\right)$ was determined.

While we did attempt to provide full coverage over the sampling period, equipment breakdowns or sample contamination - mostly by insects which drowned in the sample bottles - were a frequent occurrence. We successfully collected samples for about $40 \%$ of the totally occurring flow events.

125 Samples are digested according to the US EPA ESS digestion method 310.2 (US EPA 1992) with the addition of sulfuric acid $\left(\mathrm{H}_{2} \mathrm{SO}_{4}\right)$, ammoniumperoxidisulfate $\left(\left(\mathrm{NH}_{4}\right)_{2} \mathrm{~S}_{2} \mathrm{O}_{8}\right)$ and pressurized heating to $130{ }^{\circ} \mathrm{C}$ in an autoclave. To solubilize $\mathrm{P}$ from possible biological growth on the surfaces of sampling bottles, part of the sulfuric acid used for the digestion was added directly into the sampling bottle, acidifying the sample to $\mathrm{pH} 0.7$. The acidified samples are then shelved for three weeks and placed in to a mechanical shaker once every week, 12 hours at a time, after which the remaining steps

130 of the digestion process are carried out.

After the digestion, sample $\mathrm{pH}$ is adjusted to $\mathrm{pH} 7$ with ultra pure $\mathrm{NaOH}$ solution. This is done, because the $\mathrm{pH}$ of samples varied between 0.7 and 1.2 after the digestion, which can influence the analysis method and also cause interferences with $\mathrm{Si}$ and $\mathrm{As}$.

$\mathrm{P}_{\text {tot }}$ is measured with the molybdenum blue method by Murphy and Riley (1962) adapted by Drummond and Maher

135 (1995) using a Autolab 4 device by Green Eyes LLC. Every sample is measured 3 times, standards are interspersed at a rate of 3 standards every 14 samples. Deviations among repeated measurements on the same sample were usually below $5 \%$ of the measured value. From the repeated measurements, the range of the measurement error is calculated as the standard deviation. The error range for P loads in flow events is calculated as the accumulated total measurement error.

To avoid outside contamination during sampling and analysis as much as possible, only dedicated equipment, sample

140 containers and lab space was used, which were cleaned with deionized water and phosphate free detergent before each use. When the possibility of outside contamination was apparent, the respective samples were discarded. Possible systematic contamination was monitored through the inclusion of standards in every aspect of sample handling. This includes standards being placed in randomly chosen, open sample bottles in the autosamplers at the field sites for the time spans between sample collection dates. The standards are also subjected to the same treatment as the actual

145 samples with regard to acidification, storage and digestion. From the point of collection to the final measurement of $\mathrm{P}_{\text {tot }}$, a mass balance is documented for each sample to correct for evaporation losses during the digestion and dilution 
SOIL Discuss., https://doi.org/10.5194/soil-2018-13

Manuscript under review for journal SOIL

Discussion started: 4 June 2018

(c) Author(s) 2018. CC BY 4.0 License.

through added reagents.

For each hillslope site, time series of lateral flow rate, electric conductivity (EC), air temperature and soil moisture in the organic layer were compiled for the observation period. Intra-event data and event-wise aggregated data (called inter-event data from here on) is used to construct multiple linear models with the $\mathrm{P}_{\text {tot }}$ concentration in lateral flow as the dependent variable. Depending on the parameter, aggregated inter-event data consists of sums (flow volume), arithmetic averages (flow rate, soil moisture, air temperature) or flow weighted averages $\left(\mathrm{EC}, \mathrm{P}_{\mathrm{tot}}\right)$ of the original data. Flow events are defined according to two criteria; If only a single peak in lateral flow rate occurs within a distinct precipitation event and until the cessation of lateral flow, the whole period is regarded as a single event. If multiple flow peaks occur within a period of uninterrupted flow, the period may be split into multiple events. If the flow rate falls below $10 \%$ of the preceding flow peak before increasing again and if this increase corresponds to a prior increase in rainfall intensity, this is used as a cutoff point between events.

To identify environmental variables that may explain the observed intra- and inter-event variability in P concentration in the lateral subsurface flow and to test, whether similar relations can be established for all three sampling sites, multiple linear models are utilized. By comparing intra- with inter even data, we want to test to which extend our high resolution sampling is helpful to improve process understanding of lateral $\mathrm{P}$ transport.

The parameter selection for inter- and intra-event models respectively was carried out by stepwise forward selection/backwards elimination of variables with respect to the Akaike Information Criterion (AIC) through the step()function in the R base-environment (R-Core-Team 2014). The full set of parameters from which the algorithm choses a reduced set, contains both "real time" indicators, such as lateral flow rate, EC and soil moisture, as well as "betweenevent" indicators like time duration between events, such as average soil moisture and temperature since the last event (see Tab. 3). The IDs of the three experimental sites are included as a categorical variable, which can also serve as an error term. The "between-event" parameters are exactly the same for both model approaches, while the "real-time" parameters are represented by average values in the inter-event model and the respective raw data in intra-event models.

The relative parameter importance was calculated according to (Grömping 2006) in the R-environment.

\section{Results}

Our observations cover the full vegetation period at the the sites MIT and CON and start shortly after leafs shoot at the site VES (Tab. 2). Most precipitation events $>1 \mathrm{~mm}$ produced measurable lateral flow, totaling 151 discrete subsurface

175 flow events during the observation period on all 3 sites. Mostly due to field equipment breakdowns, only 62 of these events with a total of 417 individual samples were successfully analyzed for $\mathrm{P}_{\text {tot}}$.

While the amount of total precipitation during the observation periods was relatively similar among the three sites, the amounts of lateral flow were very different, with 7 times higher flow volume at the site MIT in comparison to site CON and the site VES almost 3 times higher in comparison to CON (Tab. 2). Since our design does not allow for the

180 determination of the source area of lateral flow, it can only be assessed as a total amount, and not as a fraction of the respective rainfall event.

-- Table 2 --

185 Soil moisture responds to precipitation events in most instances, but at the sites MIT and VES there is a regular occurrence of precipitation events that do not seem to cause changes volumetric water content in the organic layer and topsoil. Overall, there is a marked decline in soil moisture in the organic layer from mid-June to the end of the 
SOIL Discuss., https://doi.org/10.5194/soil-2018-13

Manuscript under review for journal SOIL

Discussion started: 4 June 2018

(c) Author(s) 2018. CC BY 4.0 License.

vegetation period at the sites MIT and CON (Fig. 1). The $\mathrm{P}_{\text {tot }}$ concentration in the lateral flow samples ranges from 5 mg 1-1 to below the detection limit of our method at $10 \mu \mathrm{g} 1-1$. Highest $\mathrm{P}_{\text {tot }}$ concentrations were predominantly found at the site CON, the lowest at the site VES. The range of $\mathrm{P}_{\text {tot }}$ concentrations in samples from a single event can be as large as the range of average event concentrations throughout the measurement period at a given site. The existing range of occurring $\mathrm{P}_{\text {tot }}$ concentrations allowed for the estimation of $\mathrm{P}$ loads during events with only a few percent of uncertainty in most cases (Fig. 2).

The average event concentration of $\mathrm{P}_{\text {tot }}$ in lateral flow does not show a pronounced seasonal pattern and can differ considerably among successive events (Fig. 1).

The variation of intra-event $\mathrm{P}_{\text {tot }}$ concentrations appears more ordered, with recognizable periods of increase or decrease (Fig. 2). Still, the underlying processes are not immediately recognizable, as neither flow rate, soil moisture or EC appear to be in a consistent relation with the Ptot concentration. For some events, the $\mathrm{P}_{\text {tot }}$ concentration decreases consistently over time, irregardless of changes in the flow rate, while being both positively and negatively correlated to EC (Fig 2 B,C,D). In other events, multiple peaks in the Ptot concentration are evident without a clear relation to flow peaks in the flow rate (Fig $2 \mathrm{~A}, \mathrm{E})$.

$$
\begin{aligned}
& \text {-- Figure } 1 \text { - } \\
& \text {-- Figure } 2 \text {-- } \\
& \text {-- Figure } 3 \text { - } \\
& \text {-- Table } 3 \text {-- }
\end{aligned}
$$

Results of the multiple linear models, fitted to both intra- and inter-event Ptot concentrations of lateral flow are displayed in Fig. 3 and Tab. 3. In both cases, differences between the study sites are responsible for most of the variability in $\mathrm{P}_{\text {tot }}$ concentrations of lateral flow explained by the model. The final models, were parameters were selected

210 according to the respective model AIC, contain different parameters for the intra- and inter-event data models. The total explained variability is notably higher for the model fitted to inter-event data.

\section{Discussion}

Across our sites, most measurable precipitation events produced lateral flow in turn, even when no changes in soil moisture were recorded. This is a strong indication that lateral flow is an important characteristic of the hydrological system in the organic layer and topsoil of the experimental sites. Still, there are notable differences among the sites regarding the generation of lateral flow following rainfall events. At the site MIT there is a regular occurrence of precipitation events in the summer months that do not coincident with an increase in soil moisture, but which do cause lateral flow. At the sites VES and CON, soil moisture is increased following rainfall events nearly without exception, while lateral flow is not always generated, especially in the drier summer months at the site CON. This indicates, that the fractions of rainfall that contribute to lateral and vertical flow respectively may differ between the study sites depending on the hydrological setting. The observation that generation of lateral flow is more pronounced at the site MIT than at the other sites is supported further by the observation, that the total amount of lateral flow relative to rainfall is by far highest at this site. The relatively high yields of lateral flow at the site MIT despite the fact that this sites has by far the lowest slope angle (see Tab. 1) could be an indication of hydrophobicity in the organic layer and topsoil, which might prevent the soil material from retaining water, which in turn would increase potential for lateral subsurface flow. The possible occurrence of hydrophobicity in the dry period at the site MIT might also explain that average $\mathrm{P}$ concentrations in lateral flow at this site are significantly lower in the dry period compared to the wet period before: Lower contact times of infiltrating water with soil material as well as a smaller contact area and less exchange 
SOIL Discuss., https://doi.org/10.5194/soil-2018-13

Manuscript under review for journal SOIL

Discussion started: 4 June 2018

(c) Author(s) 2018. CC BY 4.0 License.

with pre-event soil water would be expected in during periods with hydrophobic soil material, all of which may reduce the potential for P mobilization (Bogner et al. 2008; Dinh 2017).

The very high temporal variability of the flow rate, with peaks often lasting for some minutes only, confirms the need for high temporal resolution of measurements to adequately observe this parameter. Depending on the research in question, precipitation should also be measured in a comparative resolution and directly on site. Our data shows, that 30 minute resolution in precipitation measurements is not enough to match the temporal variability of lateral flow generation. At the site MIT, a distance of less than two kilometers between our field site and the meteorological station apparently was high enough to cause situations where lateral flow was measured up to an hour before precipitation onset at the rain gauge. At he field site CON, where the distance between our field site and the meteorological station was only about $100 \mathrm{~m}$ and the temporal resolution of the precipitation measurements was 5 minutes, deviations between the onset of lateral flow and precipitation were very low. These differences in the quality of precipitation data among out sites prohibited us from using precipitation as a model parameter.

Our data clearly demonstrates the existence of high temporal variability in $\mathrm{P}_{\text {tot }}$ concentrations over the course of single events as well as in average concentrations among distinct flow events. This shows that bulk sampling of single lateral flow events does not allow for generalization about average event conditions. Intra event changes in subsurface flow $\mathrm{P}_{\text {tot }}$ concentration do seem to represent orderly patterns with distinct phases of $\mathrm{P}_{\text {tot }}$ concentration in- or decreases. While outliers, where the $\mathrm{P}_{\text {tot }}$ concentration of single samples highly deviates from the rest of the event do exist, a sampling frequency from 10 to 20 minutes appears to be high enough to capture the overall event $P_{\text {tot }}$ dynamic.

Overall, lateral flow sampling in high temporal resolution actually decreases the ability of our model to predict $\mathrm{P}_{\text {tot }}$ concentrations in lateral flow when compared to the model fitted to aggregated data, which is meant to represent the results of a fictional bulk sampling approach. The high significance of both models and the minor difference between $\mathrm{R}^{2}$ and adj. $\mathrm{R}^{2}$ in the respective models (see Tab. 2) make it appear unlikely, that the additional explained variability in the inter-event data model is simply due to a reduction in sample size, or over-parametrization. Including terms for interactions between the model co-variables soil moisture, temperature and time span in between events did not significantly improve either model.

255 The AIC-dependent parameter selection algorithm chose somewhat different parameters for intra- and inter-event models. Both model structures are alike in such a way, that differences between sites (included in the model as a categorical variable) are responsible for more than half of the total explained variability. This implies that under given conditions, consistent differences in lateral subsurface flow P concentrations exist among our experimental sites.

For both models, antecedent soil moisture correlates significantly with $\mathrm{P}_{\text {tot }}$ concentration in lateral flow. Since the estimate of this parameter is positive in both cases, the models suggests that higher antecedent soil moisture is associated with higher $\mathrm{P}_{\text {tot }}$ concentration in lateral flow under given conditions. While the cumulative within-event flow volume is an important parameter in the intra-event model, total event volume is not significantly correlated to average event concentration of $\mathrm{P}_{\text {tot }}$ in the inter-event model. This indicates, that while high-volume events are not significantly associated with overall lower Ptot concentrations, there is a significant decrease of the $\mathrm{P}_{\text {tot }}$ concentration during the progression of individual events, leading on average to higher concentrations at the event start in comparison to the end. Another notable discrepancy between the two models is the effect of EC, with accounts for $18 \%$ explained variability in the inter-event model, but only for $4 \%$ in the intra-event model. This would imply, that the average values of EC during events are correlated to a higher degree to average flow and $\mathrm{P}_{\text {tot }}$ concentration, than their respective variation on intra-event timescales.

270 The negative correlation of the maximum flow rate during a respective event with $\mathrm{P}_{\text {tot }}$ in the inter-event model, as well 
SOIL Discuss., https://doi.org/10.5194/soil-2018-13

Manuscript under review for journal SOIL

Discussion started: 4 June 2018

(c) Author(s) 2018. CC BY 4.0 License.

as the low significance and explained variability of the actual flow rate in the intra-event model suggest, that immediate mobilization of transportable $\mathrm{P}$ forms in the organic layer may not be a critical process in lateral flow $\mathrm{P}_{\text {tot }}$ transport and that higher flow rates may rather cause dilution of $\mathrm{P}$ in lateral flow than lead to increased mobilization.

The fact that neither the timespan, nor the average air temperature between lateral flow events contribute significantly to either of the two models has interesting implications for the question as to where the $\mathrm{P}$ in our lateral flow samples originally came from. Precipitation is unlikely to be the main source, as typical concentrations of $\mathrm{P}_{\text {tot }}$ in throughfall are much lower than in our lateral flow samples (Sohrt et al. 2017). Also, since higher flow rates are not associated with higher $\mathrm{P}_{\text {tot }}$ concentrations, transport of particulate matter in the organic layer does not appear to be a critical process for $\mathrm{P}_{\text {tot }}$ transport. What remains as a possible source for the $\mathrm{P}_{\text {tot }}$ in our lateral flow samples, is leaching of highly transportable $\mathrm{P}$ forms from organic layer material. This leaching is thought to occur through degradation of organic layer material by plants and microbes which convert $\mathrm{P}$ bound to organic matter to soluble forms. Since microbial activity is heavily influenced by water availability and temperature, we expected periods with higher temperatures to be associated with higher $\mathrm{P}_{\text {tot }}$ concentrations in lateral flow. Our results do not show such a relation with mean air temperature, though, higher soil moisture does lead to higher $\mathrm{P}$ concentrations in lateral flow. The fact that the time spans between events are not significantly correlated to $\mathrm{P}_{\text {tot }}$ concentrations in lateral flow indicates, that little or no accumulation of water transportable $\mathrm{P}$ in the organic layer occurs in between flow events.

\section{Conclusions}

The generation of lateral flow in the organic layer in response to rainfall is very heterogeneous among our study sites, and so is the $\mathrm{P}_{\text {tot }}$ transport associated to it. Average $\mathrm{P}_{\text {tot }}$ concentration in lateral flow was not proportional to $\mathrm{P}$ concentration or -content of the organic layer material at the respective site. This strongly suggests, that generalizations about lateral flow and the associated $\mathrm{P}$ transport from case studies into a broader context have to be treated with caution. This is empathized by our model results in which the site ID, which may also serve as a site specific error term, was by far the most significant parameter regarding $\mathrm{P}$ transport in the organic layer.

295 The fact that the set of environmental data we used to explain the $\mathrm{P}$ transport only accounted for 20-30\% explained variability demonstrates, that our understanding of its underlying causes is still limited. What our results clearly show is, that simple scenarios for $\mathrm{P}$ transport in this context are not feasible. Neither water flow as the mobilizing force, nor accumulation of transportable $\mathrm{P}$ in the organic layer in between events can be supported as primary regulators for $\mathrm{P}$ transport in lateral flow by our study. Our advice to future researchers on this topic would be to focus on detailed case studies and controlled experiments in the field, rather than on large spatial and temporal coverage. This would allow for the use of artificial tracers as well as the distinction between different P species in lateral flow, which may help in determining the drivers of organic layer $\mathrm{P}$ transport with later flow. 
SOIL Discuss., https://doi.org/10.5194/soil-2018-13

Manuscript under review for journal SOIL

Discussion started: 4 June 2018

(c) Author(s) 2018. CC BY 4.0 License.

Code availability

The authors do not plan to make the code underlying this study publicly available.

Data availability

310 Upon acceptance of the manuscript for publication, the complete raw data the study is based on will be deposited in a suitable public data repository.

Sample availability

The samples used in this study are not IGSN-registered.

Appendices and supplements

There are no appendices and supplements for this publication.

Author contributions

320 Jakob Sohrt collected the data used in this study with the exception of meteorological data, which was provided by the federal forest research institutes of Bavaria and Baden-Württemberg. Jakob Sohrt takes responsibility for the integrity of the data and the accuracy of the data analysis. All listed authors comply with the journals authorship policy.

Conflict of interest

The authors declare no conflict of interest.

Acknowledgments

This study was carried out under a grant from the DFG funded project SPP 1685 Ecosystem Nutrition, Forest Strategies for limited Phosphorus Resources under the project ID WE 4598/7-1. On site information on meteorological conditions and soil moisture was kindly provided by the federal forest research institutes of Bavaria and Baden-Württemberg. We thank Delon Wagner, Ruth Magh, Franziska Zieger and Lisa Dankwerth for their help with field work and sample handling. 
SOIL Discuss., https://doi.org/10.5194/soil-2018-13

Manuscript under review for journal SOIL

Discussion started: 4 June 2018

(c) Author(s) 2018. CC BY 4.0 License.

\section{References}

Attiwill, P. M. and Adams, M. A. Nutrient cycling in forests, New Phytol. 124:561-582, doi: 10.1111/j.1469-

8137.1993.tb03847.x, 1993.

Aubertin, G. M. Nature and extent of macropores in forest soils and their influence on subsurface water movement, Res.

Pap. NE-192, doi: , 1971.

Bachmair, S. and Weiler, M. Hillslope characteristics as controls of subsurface flow variability, HESS 16:3699-3715, doi: 10.5194/hess-16-3699-2012, 2012a.

Bachmair, S. and Weiler, M., Technical report on experimental hillslope hydrology, (Hydronotes, University of Freiburg), Freiburg,University of Freiburg, Germany 2012 b.

345 Bachmair, S.; Weiler, M. and Nützmann, G. Controls of land use and soil structure on water movement: Lessons for pollutant transfer through the unsaturated zone, J. Hydrol. 369:241-252, doi: 10.1016/j.jhydrol.2009.02.031, 2009.

Bachmair, S.; Weiler, M. and Troch, P. A. Intercomparing hillslope hydrological dynamics: Spatio-temporal variability and vegetation cover effects, Water Resour. Res. 48, doi: 10.1029/2011WR011196, 2012.

Beaulac, M. N. and Reckhow, K. H. An examination of land use-nutrient export relationships, J. Am. Water Resour. Assoc. 18:1013-1024, doi: 10.1111/j.1752-1688.1982.tb00109.x, 1982.

Bergkemper, F.; Bünemann, E. K.; Hauenstein, S.; Heuck, C.; Kandeler, E.; Krüger, J.; Marhan, S.; Mészáros, É.; Nassal, D.; Nassal, P. and others An inter-laboratory comparison of gaseous and liquid fumigation based methods for measuring microbial phosphorus (P mic) in forest soils with differing P stocks, J. Microbiol. Methods 128:66-68, doi: 10.1016/j.mimet.2016.07.006, 2016.

Bergkemper, F.; Schöler, A.; Engel, M.; Lang, F.; Krüger, J.; Schloter, M. and Schulz, S. Phosphorus depletion in forest soils shapes bacterial communities towards phosphorus recycling systems, Environ. Microbiol. 18:1988-2000, doi: 10.1111/1462-2920.13188, 2016.

Beven, K. and Germann, P. Macropores and water flow in soils, Water Resour. Res. 18:1311-1325, doi: 10.1002/wrcr.20156, 1982.

360 Beven, K. and Germann, P. Macropores and water flow in soils revisited, Water Resour. Res. 49:3071-3092, doi: 10.1029/WR018i005p01311, 2013.

Björkman, E. and Lundeberg, G., Studies of root competition in a poor pine forest by supply of labelled nitrogen and phosphorus, technical report, Sveriges lantbruksuniversitet, Sweden, 1971.

Bogner, C.; Wolf, B.; Schlather, M. and Huwe, B. Analysing flow patterns from dye tracer experiments in a forest soil using extreme value statistics, Eur. J. Soil Sci. 59:103-113, doi: , 2008.

Bol, R.; Julich, D.; Brödlin, D.; Siemens, J.; Kaiser, K.; Dippold, M. A.; Spielvogel, S.; Zilla, T.; Mewes, D.; von Blanckenburg, F. and others Dissolved and colloidal phosphorus fluxes in forest ecosystems — an almost blind spot in ecosystem research, J. Plant Nutr. Soil Sci. 179:425-438, doi: 10.1002/jpln.201600079, 2016.

Buendia, C.; Kleidon, A. and Porporato, A. The role of tectonic uplift, climate, and vegetation in the long-term terrestrial phosphorous cycle, Biogeosciences 7:2025-2038, doi: 10.5194/bg-7-2025-2010, 2010. 
SOIL Discuss., https://doi.org/10.5194/soil-2018-13

Manuscript under review for journal SOIL

Discussion started: 4 June 2018

(c) Author(s) 2018. CC BY 4.0 License.

Bundt, M.; Widmer, F.; Pesaro, M.; Zeyer, J. and Blaser, P. Preferential flow paths: biological 'hot spots' in soils, Soil. Biol. Biochem. 33:729-738, doi: 10.1016/S0038-0717(00)00218-2, 2001.

Bünemann, E.; Augstburger, S. and Frossard, E. Dominance of either physicochemical or biological phosphorus cycling processes in temperate forest soils of contrasting phosphate availability, Soil. Biol. Biochem. 101:85-95, doi: 10.1016/j.soilbio.2016.07.005, 2016.

Burns, D. A.; Hooper, R. P.; McDonnell, J. J.; Freer, J. E.; Kendall, C. and Beven, K. Base cation concentrations in subsurface flow from a forested hillslope: The role of flushing frequency, Water Resour. Res 34:3535-3544, doi: 10.1029/98WR02450, 1998.

Clark, D. A.; Brown, S.; Kicklighter, D. W.; Chambers, J. Q.; Thomlinson, J. R. and Ni, J. Measuring net primary production in forests: concepts and field methods, Ecol. Appl. 11:356-370, doi: 10.1890/10510761(2001)011[0356:MNPPIF]2.0.CO;2, 2001.

Cole, D. W. and Rapp, M. O., Elemental cycling in forest ecosystems, in: Dynamic properties of forest ecosystems, Reichele, D. E. (Ed.), Cambridge University Press, Cambridge, United Kingdom, 1981.

Compton, J. E. and Cole, D. W. Phosphorus cycling and soil P fractions in Douglas-fir and red alder stands, For. Ecol.

Manage. 110:101-112, doi: 10.1016/S0378-1127(98)00278-3, 1998.

R-Core-Team, R: A language and environment for statistical computing. R Foundation for Statistical Computing, Vienna, Austria, 2014.

Cox, J.; Kirkby, C.; Chittleborough, D.; Smythe, L. and Fleming, N. Mobility of phosphorus through intact soil cores collected from the Adelaide Hills, South Australia, Soil Res. 38:973-990, doi: 10.1071/SR99125, 2000.

390 Dillon, P. J. and Kirchner, W. The effects of geology and land use on the export of phosphorus from watersheds, Water Res. 9:135-148, doi: 10.1016/0043-1354(75)90002-0, 1975.

Dinh, M.-V., Soluble Phosphorus in Forest Soil: Effects of Drying and Rewetting, P.hD, Universität Bayreuth, Bayreuth, Germany, 2017.

Drummond, L. and Maher, W. Determination of phosphorus in aqueous solution via formation of the

395 phosphoantimonylmolybdenum blue complex. Re-examination of optimum conditions for the analysis of phosphate, Anal. Chim. Acta 302:69-74, doi: 10.1016/0003-2670(94)00429-P, 1995.

Eckstein, R. L.; Karlsson, P. and Weih, M. Leaf life span and nutrient resorption as determinants of plant nutrient conservation in temperate-arctic regions, New Phytol. 143:177-189, doi: 10.1046/j.1469-8137.1999.00429.x, 1999.

Elser, J. J.; Bracken, M. E. S.; Cleland, E. E.; Gruner, D. S.; Harpole, W. S.; Hillebrand, H.; Ngai, J. T.; Seabloom, E. W.; 400 Shurin, J. B. and Smith, J. E. Global analysis of nitrogen and phosphorus limitation of primary producers in freshwater, marine and terrestrial ecosystems, Ecol. Lett. 10:1135-1142, doi: 10.1111/j.1461-0248.2007.01113.x, 2007.

Elser, J. J.; Fagan, W. F.; Denno, R. F.; Dobberfuhl, D. R.; Folarin, A.; Huberty, A.; Interlandi, S.; Kilham, S. S.; McCauley, E.; Schulz, K. L. and others Nutritional constraints in terrestrial and freshwater food webs, Nature 408:578580, doi: 10.1038/35046058, 2000.

405 Fisk, M. C. and Fahey, T. J. Microbial biomass and nitrogen cycling responses to fertilization and litter removal in young northern hardwood forests, Biogeochemistry 53:201-223, doi: 10.1023/A:1010693614196, 2001. 
SOIL Discuss., https://doi.org/10.5194/soil-2018-13

Manuscript under review for journal SOIL

Discussion started: 4 June 2018

(c) Author(s) 2018. CC BY 4.0 License.

Fitzhugh, R. D.; Driscoll, C. T.; Groffman, P. M.; Tierney, G. L.; Fahey, T. J. and Hardy, J. P. Effects of soil freezing disturbance on soil solution nitrogen, phosphorus, and carbon chemistry in a northern hardwood ecosystem,

Biogeochemistry 56:215-238, doi: 10.1023/A:1013076609950, 2001.

Fuchs, J. W.; Fox, G. A.; Storm, D. E.; Penn, C. J. and Brown, G. O. Subsurface transport of phosphorus in riparian floodplains: Influence of preferential flow paths, J. Environ. Qual. 38:473-484, doi: 10.2134/jeq2008.0201, 2009.

Gaudinski, J. B.; Trumbore, S. E.; Davidson, E. A. and Zheng, S. Soil carbon cycling in a temperate forest: radiocarbon-based estimates of residence times, sequestration rates and partitioning of fluxes, Biogeochemistry 51:3369, doi: 10.1023/A:1006301010014, 2000.

Goldberg, D. E., Components of resource competition in plant communities, in: Components of resource competition in plant communities, Grace J B, T. D. (Ed.), Academic Press, Inc., University of Michigan, Ann Arbor, USA, 1990.

Gosz, J. R.; Likens, G. E. and Bormann, F. H. Nutrient content of litter fall on the Hubbard Brook experimental forest, New Hampshire, Ecology 53:769-784, doi: 10.2307/1934293, 1972.

Grömping, U. Relative importance for linear regression in R: the package relaimpo, J. Stat. Softw. 17:1-27, doi: 10.18637/jss.v017.i01, 2006.

Hättenschwiler, S. and Vitousek, P. M. The role of polyphenols in terrestrial ecosystem nutrient cycling, Trends in Ecology \& Evolution 15:238-243, doi: 10.1016/S0169-5347(00)01861-9, 2000.

Haußmann, T. and Lux, W. Dauerbepobachtungsflächen zur Umweltkontrolle im Wald: Level II, BMELF, erste Ergebnisse, Bonn, Germany, doi: , 1997.

425 Hill, A.; Kemp, W.; Buttle, J. and Goodyear, D. Nitrogen chemistry of subsurface storm runoff on forested Canadian Shield hillslopes, Water Resour. Res 35:811-821, doi: 10.1029/1998WR900083, 1999.

Holzmann, S.; Missong, A.; Puhlmann, H.; Siemens, J.; Bol, R.; Klumpp, E. and Wilpert, K. v. Impact of anthropogenic induced nitrogen input and liming on phosphorus leaching in forest soils, J. Plant Nutr. Soil Sci. 179:443453, doi: 10.1002/jpln.201500552, 2016.

$430 \quad$ Ilg, K.; Wellbrock, N. and Lux, W. Phosphorus supply and cycling at long-term forest monitoring sites in Germany, Eur. J. For. Res. 128:483-492, doi: 10.1007/s10342-009-0297-z, 2009.

Jardine, P.; Wilson, G.; McCarthy, J.; Luxmoore, R.; Taylor, D. and Zelazny, L. Hydrogeochemical processes controlling the transport of dissolved organic carbon through a forested hillslope, J. Contam. Hydrol. 6:3-19, doi: 10.1016/0169-7722(90)90008-5, 1990.

435 Jarvis, N. J. A review of non-equilibrium water flow and solute transport in soil macropores: Principles, controlling factors and consequences for water quality, Eur. J. Soil Sci. 58:523-546, doi: 10.1111/j.1365-2389.2007.00915.x, 2007.

Jensen, M. B.; Hansen, H. C. B. and Magid, J. Phosphate sorption to macropore wall materials and bulk soil, Water. Air. Soil Pollut. 137:141-148, doi: 10.1023/A:1015589011729, 2002.

Johnson, D. W.; Trettin, C. C. and Todd, D. E. Changes in forest floor and soil nutrients in a mixed oak forest 33 years

440 after stem only and whole-tree harvest, For. Ecol. Manage. 361:56-68, doi: 10.1016/j.foreco.2015.11.012, 2016.

Julich, D.; Julich, S. and Feger, K.-H. Phosphorus in Preferential Flow Pathways of Forest Soils in Germany, Forests 8:19, doi: 10.3390/f8010019, 2016. 
SOIL Discuss., https://doi.org/10.5194/soil-2018-13

Manuscript under review for journal SOIL

Discussion started: 4 June 2018

(c) Author(s) 2018. CC BY 4.0 License.

Julich, D.; Julich, S. and Feger, K.-H. Phosphorus fractions in preferential flow pathways and soil matrix in hillslope soils in the Thuringian Forest (Central Germany), J. Plant Nutr. Soil Sci. 180:407-417, doi: 10.1002/jpln.201600305, 2017.

Kaiser, K. and Guggenberger, G. Mineral surfaces and soil organic matter, Eur. J. Soil Sci. 54:219-236, doi: 10.1046/j.1365-2389.2003.00544.x, 2003.

Kaiser, K.; Guggenberger, G.; Haumaier, L. and Zech, W. Seasonal variations in the chemical composition of dissolved organic matter in organic forest floor layer leachates of old-growth Scots pine (Pinus sylvestris L.) and European beech (Fagus sylvatica L.) stands in northeastern Bavaria, Germany, Biogeochemistry 55:103-143, doi: 10.1023/A:1010694032121, 2001a.

Kaiser, K.; Guggenberger, G. and Zech, W. Organically bound nutrients in dissolved organic matter fractions in seepage and pore water of weakly developed forest soils, Acta Hydrochim. Hydrobiol. 28:411-419, doi: 10.1002/1521401X(20017)28:7<411::AID-AHEH411>3.0.CO;2-D, 2001b.

Keim, R. F.; Skaugset, A. E. and Weiler, M. Temporal persistence of spatial patterns in throughfall, J. Hydrol. 314:263274, doi: https://doi.org/10.1016/j.jhydrol.2005.03.021, 2005.

Lang, F.; Bauhus, J.; Frossard, E.; George, E.; Kaiser, K.; Kaupenjohann, M.; Krüger, J.; Matzner, E.; Polle, A.; Prietzel, J. and others Phosphorus in forest ecosystems: New insights from an ecosystem nutrition perspective, J. Plant Nutr. Soil Sci. 179:129-135, doi: 10.1002/jpln.201500541, 2016.

460 Lang, F.; Krüger, J.; Amelung, W.; Willbold, S.; Frossard, E.; Bünemann, E. K.; Bauhus, J.; Nitschke, R.; Kandeler, E.; Marhan, S.; Schulz, S.; Bergkemper, F.; Schloter, M.; Luster, J.; Guggisberg, F.; Kaiser, K.; Mikutta, R.; Guggenberger, G.; Polle, A.; Pena, R.; Prietzel, J.; Rodionov, A.; Talkner, U.; Meesenburg, H.; von Wilpert, K.; Hölscher, A.; Dietrich, H. P. and Chmara, I. Soil phosphorus supply controls P nutrition strategies of beech forest ecosystems in Central Europe, Biogeochemistry 136:5-29, doi: 10.1007/s10533-017-0375-0, 2017.

465 Mahowald, N.; Jickells, T. D.; Baker, A. R.; Artaxo, P.; Benitez-Nelson, C. R.; Bergametti, G.; Bond, T. C.; Chen, Y.; Cohen, D. D.; Herut, B. and others Global distribution of atmospheric phosphorus sources, concentrations and deposition rates, and anthropogenic impacts, Global Biogeochem. Cycles 22, doi: 10.1029/2008GB003240, 2008.

Missong, A.; Bol, R.; Willbold, S.; Siemens, J. and Klumpp, E. Phosphorus forms in forest soil colloids as revealed by liquid-state 31P-NMR, J. Plant Nutr. Soil Sci. 179:159-167, doi: 10.1002/jpln.201500119, 2016.

470 Murphy, J. and Riley, J. P. A modified single solution method for the determination of phosphate in natural waters, Anal. Chim. Acta 27:31-36, doi: 10.1016/S0003-2670(00)88444-5, 1962.

Netzer, F.; Schmid, C.; Herschbach, C. and Rennenberg, H. Phosphorus-nutrition of European beech (Fagus sylvatica L.) during annual growth depends on tree age and P-availability in the soil, Environ. Exp. Bot. 137:194-207, doi: 10.1016/j.envexpbot.2017.02.009, 2017.

475 Newman, B. D.; Campbell, A. R. and Wilcox, B. P. Lateral subsurface flow pathways in a semiarid ponderosa pine hillslope, Water Resour. Res 34:3485-3496, doi: 10.1029/98WR02684, 1998.

Newman, E. I. Phosphorus inputs to terrestrial ecosystems, J. Ecol. 83:713-726, doi: 10.2307/2261638, 1995.

O'neill, R. and DeAngelis, D., Comparative productivity and biomass relations of forest ecosystems, in: Dynamic properties of forest ecosystems, Reichele D, E. (Ed.), Cambridge University Press, Cambridge, 1981. 
SOIL Discuss., https://doi.org/10.5194/soil-2018-13

Manuscript under review for journal SOIL

Discussion started: 4 June 2018

(c) Author(s) 2018. CC BY 4.0 License.

480 Prietzel, J.; Klysubun, W. and Werner, F. Speciation of phosphorus in temperate zone forest soils as assessed by combined wet-chemical fractionation and XANES spectroscopy, J. Plant Nutr. Soil Sci. 179:168-185, doi: 10.1002/jpln.201500472, 2016.

Qualls, R. G.; Haines, B. L.; Swank, W. T. and Tyler, S. W. Retention of soluble organic nutrients by a forested ecosystem, Biogeochemistry 61:135-171, doi: 10.1023/A:1020239112586, 2002.

Reckhow, K. H.; Beaulac, M. N. and Simpson, J. T., EPA, Michigan State University, Modeling phosphorus loading and lake response under uncertainty: A manual and compilation of export coefficients, 1980.

Schwärzel, K.; Ebermann, S. and Schalling, N. Evidence of double-funneling effect of beech trees by visualization of flow pathways using dye tracer, J. Hydrol. 470:184-192, doi: 10.1016/j.jhydrol.2012.08.048, 2012.

Sohrt, J.; Lang, F. and Weiler, M. Quantifying components of the phosphorus cycle in temperate forests, Wiley Interdiscip. Rev. Wat. 4:e1243, doi: 10.1002/wat2.1243, 2017.

Timmons, D.; Verry, E.; Burwell, R. and Holt, R. Nutrient transport in surface runoff and interflow from an aspen-birch forest, J. Environ. Qual. 6:188-192, doi: 10.2134/jeq1977.00472425000600020018x, 1977.

Tipping, E.; Benham, S.; Boyle, J.; Crow, P.; Davies, J.; Fischer, U.; Guyatt, H.; Helliwell, R.; Jackson-Blake, L.; Lawlor, A. J. and others Atmospheric deposition of phosphorus to land and freshwater, Environmental Science:

Processes \& Impacts 16:1608-1617, doi: 10.1039/C3EM00641G, 2014.

Turner, B. L.; Lambers, H.; Condron, L. M.; Cramer, M. D.; Leake, J. R.; Richardson, A. E. and Smith, S. E. Soil microbial biomass and the fate of phosphorus during long-term ecosystem development, Plant Soil 367:225-234, doi: 10.1007/s11104-012-1493-z, 2013.

US EPA, Environmental Sciences Section Inorganic Chemistry Unit, Wisconsin State Lab of Hygiene 465 Henry Mall Madison, WI 53706, ESS Method 310.2: Phosphorus, Total, Low Level (Persulfate Digestion), 1992.

Vinther, F. P.; Eiland, F.; Lind, A. and Elsgaard, L. Microbial biomass and numbers of denitrifiers related to macropore channels in agricultural and forest soils, Soil. Biol. Biochem. 31:603-611, doi: 10.1016/S0038-0717(98)00165-5, 1999.

Vuorenmaa, J.; Rekolainen, S.; Lepistö, A.; Kenttämies, K. and Kauppila, P. Losses of nitrogen and phosphorus from agricultural and forest areas in Finland during the 1980s and 1990s, Environ. Monit. Assess. 76:213-248, doi: 10.1023/A:1015584014417, 2002.

Wood, T.; Bormann, F. and Voigt, G. Phosphorus cycling in a northern hardwood forest: biological and chemical control, Science 223:391-393, doi: 10.1126/science.223.4634.391, 1984.

Yanai, R. D. Phosphorus budget of a 70-year-old northern hardwood forest, Biogeochemistry 17:1-22, doi: 10.1007/BF00002757, 1992.

510 Zavišić, A.; Nassal, P.; Yang, N.; Heuck, C.; Spohn, M.; Marhan, S.; Pena, R.; Kandeler, E. and Polle, A. Phosphorus availabilities in beech (Fagus sylvatica L.) forests impose habitat filtering on ectomycorrhizal communities and impact tree nutrition, Soil. Biol. Biochem. 98:127-137, doi: 10.1016/j.soilbio.2016.04.006, 2016.

Zederer, D. P.; Talkner, U.; Spohn, M. and Joergensen, R. G. Microbial biomass phosphorus and C/N/P stoichiometry in forest floor and A horizons as affected by tree species, Soil. Biol. Biochem. 111:166-175, doi: 
SOIL Discuss., https://doi.org/10.5194/soil-2018-13

Manuscript under review for journal SOIL

Discussion started: 4 June 2018

(c) Author(s) 2018. CC BY 4.0 License.

SOIL

Discussions

(c) (i)

Page 15

Table 1 Stand parameters of our field sites.

\begin{tabular}{|c|c|c|c|}
\hline site & Vessertal (VES) & Mitterfels (MIT) & Conventwald (CON) \\
\hline location & $\begin{array}{l}50^{\circ} 36^{\prime} 20.8^{\prime \prime} \mathrm{N} \\
10^{\circ} 46^{\prime} 17.1^{\prime \prime} \mathrm{E}\end{array}$ & $\begin{array}{l}48^{\circ} 58^{\prime} 33.4^{\prime \prime} \mathrm{N} \\
12^{\circ} 52^{\prime} 33.5^{\prime \prime} \mathrm{E}\end{array}$ & $48^{\circ} 01^{\prime} 15.9^{\prime \prime} \mathrm{N} 7^{\circ} 57^{\prime} 56.1 " \mathrm{E}$ \\
\hline mean precipitation $\left(\mathrm{mm} \mathrm{a}^{-1}\right)^{\mathrm{a}}$ & 1200 & 1229 & 1749 \\
\hline mean temperature $\left({ }^{\circ} \mathbf{C}\right)^{\mathrm{a}}$ & 5.5 & 4.7 & 6.6 \\
\hline elevation $(\mathrm{m} \text { asl })^{\mathrm{a}}$ & 810 & 1023 & 884 \\
\hline vegetation $^{\mathbf{b}}$ & $\begin{array}{c}\text { Fagus sylvatica } 94 \%, \\
\text { Picea abies } 2 \% \text {, Abies } \\
\text { alba } 2 \%\end{array}$ & $\begin{array}{c}\text { Fagus sylvatica } \\
100 \%\end{array}$ & $\begin{array}{c}\text { Fagus sylvatica } 69 \% \text {, } \\
\text { Abies alba } 31 \%\end{array}$ \\
\hline stand age $(a)^{a}$ & 120 & 110 & $100-150$ \\
\hline slope angle at trench site $\left(^{\circ}\right)$ & 15 & 8 & 22 \\
\hline slope exposition & east-south-east & west & south \\
\hline humus form ${ }^{b}$ & moder & moder & more-like moder \\
\hline texture topsoil $^{b}$ & loam & loam & loam \\
\hline soil stone content $\%^{b}$ & 63 & 25 & 69 \\
\hline geology ${ }^{a}$ & Trachyandesite & Paragneiss & Paragneiss \\
\hline org. layer thickness $(\mathrm{cm})^{\text {b }}$ & 14 & 8 & 13 \\
\hline org. layer mass $\left(\mathrm{tha}^{-1}\right)^{\mathrm{b}}$ & 139.3 & 50.5 & 117.4 \\
\hline org. layer $P_{\text {tot }}$ conc. $\left(\mu \mathrm{g} \mathrm{g}^{-1}\right)^{b_{*}}$ & 1333.7 & 1380.7 & 1147.7 \\
\hline mineral soil $P_{\text {tot }}$ conc. $\left(\mu \mathrm{g} \mathrm{g}^{-1}\right)^{b_{*}}$ & 991.7 & 906.8 & 581.9 \\
\hline org. layer P pool $\left(\mathrm{kg} \mathrm{ha}^{-1}\right)^{\mathrm{b}}$ & 193.39 & 69.03 & 159.53 \\
\hline total soil $\mathrm{P}$ pool to $1 \mathrm{~m}\left(\mathrm{~kg} \mathrm{ha}^{-1}\right)^{b}$ & 464 & 678 & 231 \\
\hline
\end{tabular}

a: (Haußmann and Lux 1997), original source not available, cited from (Zavišić et al. 2016)

b: (Lang et al. 2017), *: mass weighted average calculated from supplementary material from (Lang et al. 2017) 
SOIL Discuss., https://doi.org/10.5194/soil-2018-13

Manuscript under review for journal SOIL

Discussion started: 4 June 2018

(c) Author(s) 2018. CC BY 4.0 License.

sou EGG

(c) (i)

Page 16

Table 2 Length of observation period, total observed precipitation and lateral flow at the three study sites during the period.

\begin{tabular}{|l|l|c|c|c|}
\hline Site & \multicolumn{2}{|l|}{ MIT } & VES & CON \\
\hline Period & & $\begin{array}{c}2015-04-01 \text { to } \\
2015-10-19\end{array}$ & $\begin{array}{c}2015-05-08 \text { to } \\
2015-10-10\end{array}$ & $2015-02-23$ to \\
& & $2015-11-21$ \\
\hline Period length & days & 523 & 155 & 271 \\
\hline Total precipitation & mm & 1409 & 421.4 & 549.4 \\
\hline Total lateral flow & 1 & & 496.8 & 205.6 \\
\hline
\end{tabular}


SOIL Discuss., https://doi.org/10.5194/soil-2018-13

Manuscript under review for journal SOIL

Discussion started: 4 June 2018

(c) Author(s) 2018. CC BY 4.0 License.

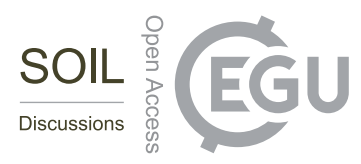

(c) (1)

Page 17

Table 3 Parameterization of multiple linear models to predict the $P_{\text {tot }}$ concentration in lateral flow. The full parameter set as well as the optimized parameter selection according to minimized AIC and their corresponding estimate, p-value and individual explained variability are shown. Parameters written in bold are included in the final model structure. Total model $R^{2}$ was 0.58 and 0.70 for the intra-event and inter-event model respectively, total model adj. $R^{2}$ was 0.57 and 0.67 respectively.

\begin{tabular}{|c|c|c|c|c|c|c|c|}
\hline $\begin{array}{l}\text { Intra-event data model } \\
\text { see fig. } 3 \mathrm{~A}\end{array}$ & estimate & p-value & $\begin{array}{l}\text { expl. } \\
\text { var. } \%\end{array}$ & $\begin{array}{l}\text { Inter event data model } \\
\text { see fig. } 3 \mathrm{~B}\end{array}$ & estimate & p-value & $\begin{array}{l}\text { expl. } \\
\text { var. \% }\end{array}$ \\
\hline site MIT (intercept) & 2.03005 & $<2 \mathrm{e}-16$ & & site MIT (intercept) & -0.312676 & 0.554926 & \\
\hline site VES & -0.2832 & $9.08 \mathrm{e}-8$ & 35.95 & site VES & 0.355078 & 0.052979 & 41.41 \\
\hline site CON & 0.59732 & $<2 \mathrm{e}-16$ & & site CON & 0.95509 & $4.35 \mathrm{e}-08$ & \\
\hline flow rate $\log 10\left(1 \mathrm{~s}^{-1}\right)$ & 0.07284 & 0.0398 & 1.53 & mean flow rate $\log 10\left(1 \mathrm{~s}^{-1}\right)$ & & & \\
\hline & & & & max flow rate $\log 10\left(1 \mathrm{~s}^{-1}\right)$ & -0.20103 & 0.012913 & 8.88 \\
\hline cum. event volume $\log 10$ (I) & -0.2124 & $<2.1 \mathrm{e}-11$ & 8.69 & event flow sum $\log 10$ (1) & & & \\
\hline $\mathrm{EC} \log 10\left(\mu \mathrm{Si} \mathbf{c m}^{-1}\right)$ & 0.18218 & $7.67 \mathrm{e}-11$ & 4.1 & mean EC $\log 10\left(\mu \mathrm{Si} \mathbf{c m}^{-1}\right)$ & 0.981421 & $1.45 \mathrm{e}-05$ & 18.59 \\
\hline soil moisture (\%) & & & & mean soil moisture $(\%)$ & & & \\
\hline mean air temp. since last & & & & mean air temp. since last event & & & \\
\hline event $\left({ }^{\circ} \mathrm{C}\right)$ & & & & $\left({ }^{\circ} \mathrm{C}\right)$ & & & \\
\hline $\begin{array}{l}\text { mean soil moisture since last } \\
\text { event }(\%)\end{array}$ & 0.04006 & $<2 \mathrm{e}-16$ & 7.78 & $\begin{array}{l}\text { mean soil moisture since last } \\
\text { event }(\%)\end{array}$ & 0.037857 & 0.000115 & 4.79 \\
\hline time since last event (h) & & & & time since last event (h) & & & \\
\hline Complete model & & $<2.2 \mathrm{e}-16$ & 58.07 & Complete model & & $1.001 \mathrm{e}-11$ & 70.55 \\
\hline
\end{tabular}


SOIL Discuss., https://doi.org/10.5194/soil-2018-13

Manuscript under review for journal SOIL

Discussion started: 4 June 2018

(c) Author(s) 2018. CC BY 4.0 License.

SOIL

Discussions

\section{(c) (1)}

Page 18
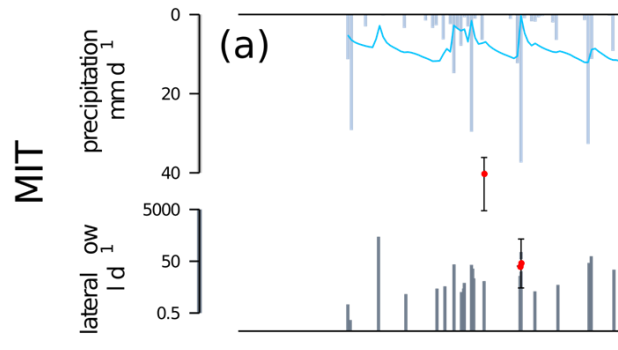

$$
\text { ๒ }
$$
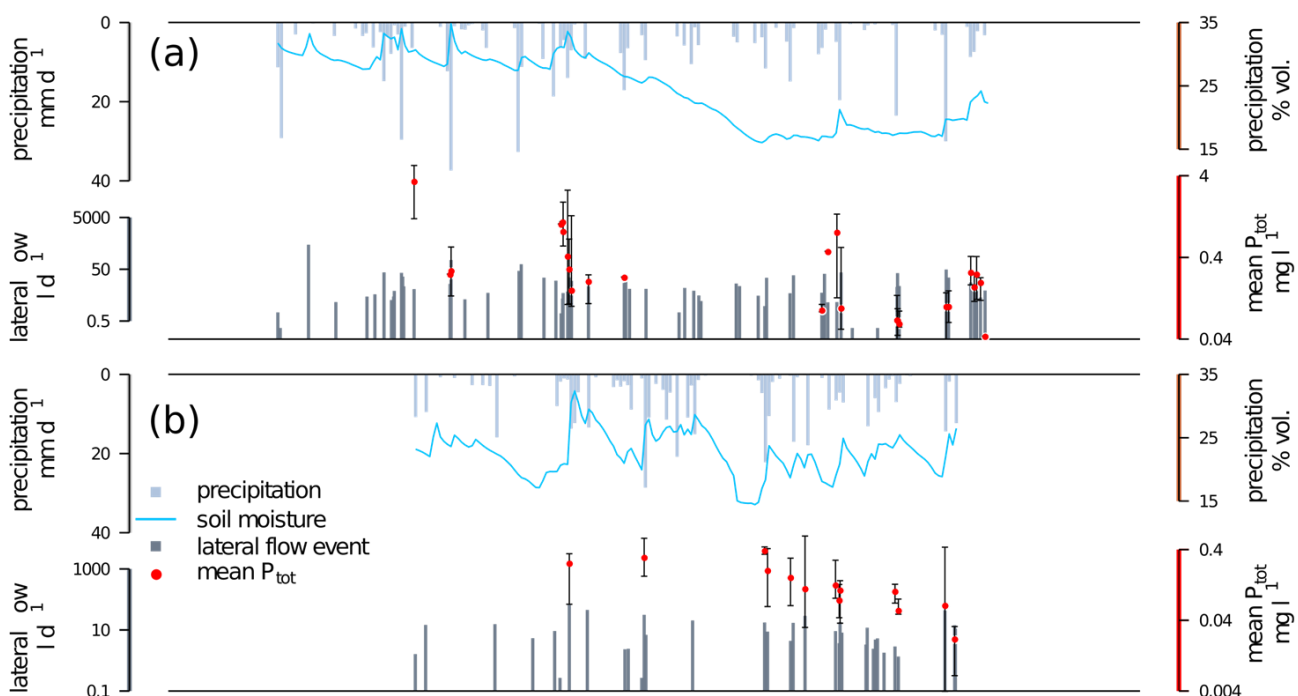

$$
\text { 急 }
$$$$
\text { 己气 }
$$

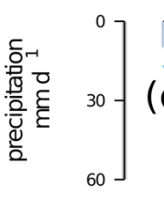

(c)
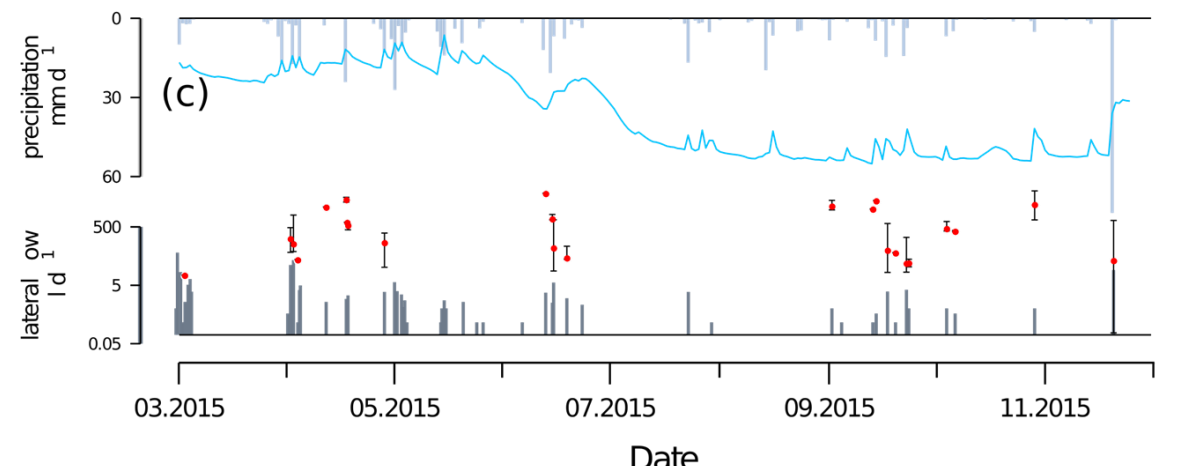

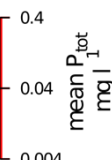

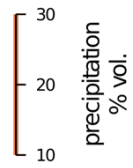

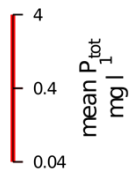

Date

Figure 1 Overview of precipitation, soil moisture, rate of lateral flow, mean (red dots) and range (error bars) of $P_{\text {tot }}$ concentration in lateral flow at the study sites Mitterfels (a), Vessertal (b) and Conventwald (c) during the observation period. 
SOIL Discuss., https://doi.org/10.5194/soil-2018-13

Manuscript under review for journal SOIL

Discussion started: 4 June 2018

(c) Author(s) 2018. CC BY 4.0 License.
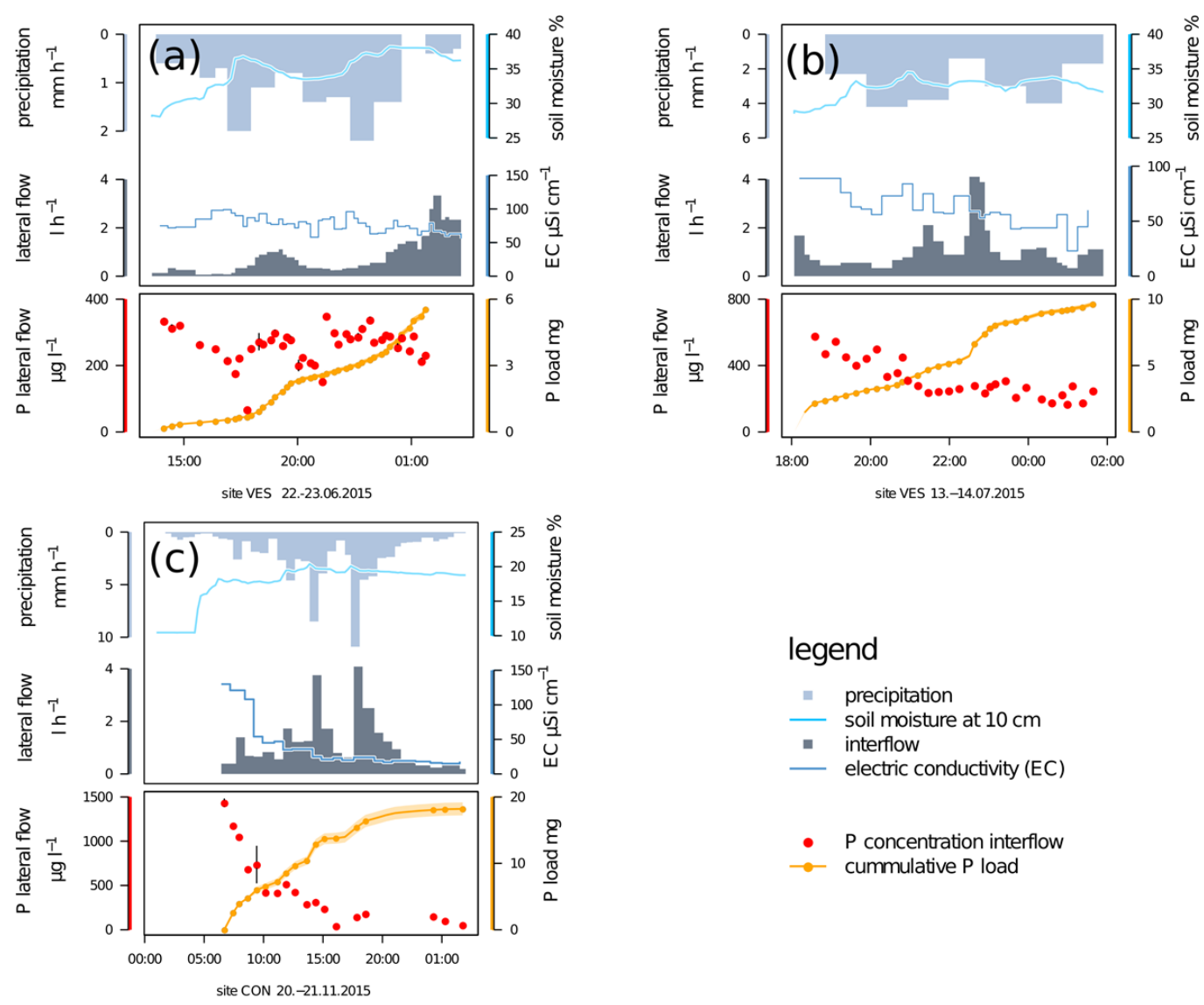

legend
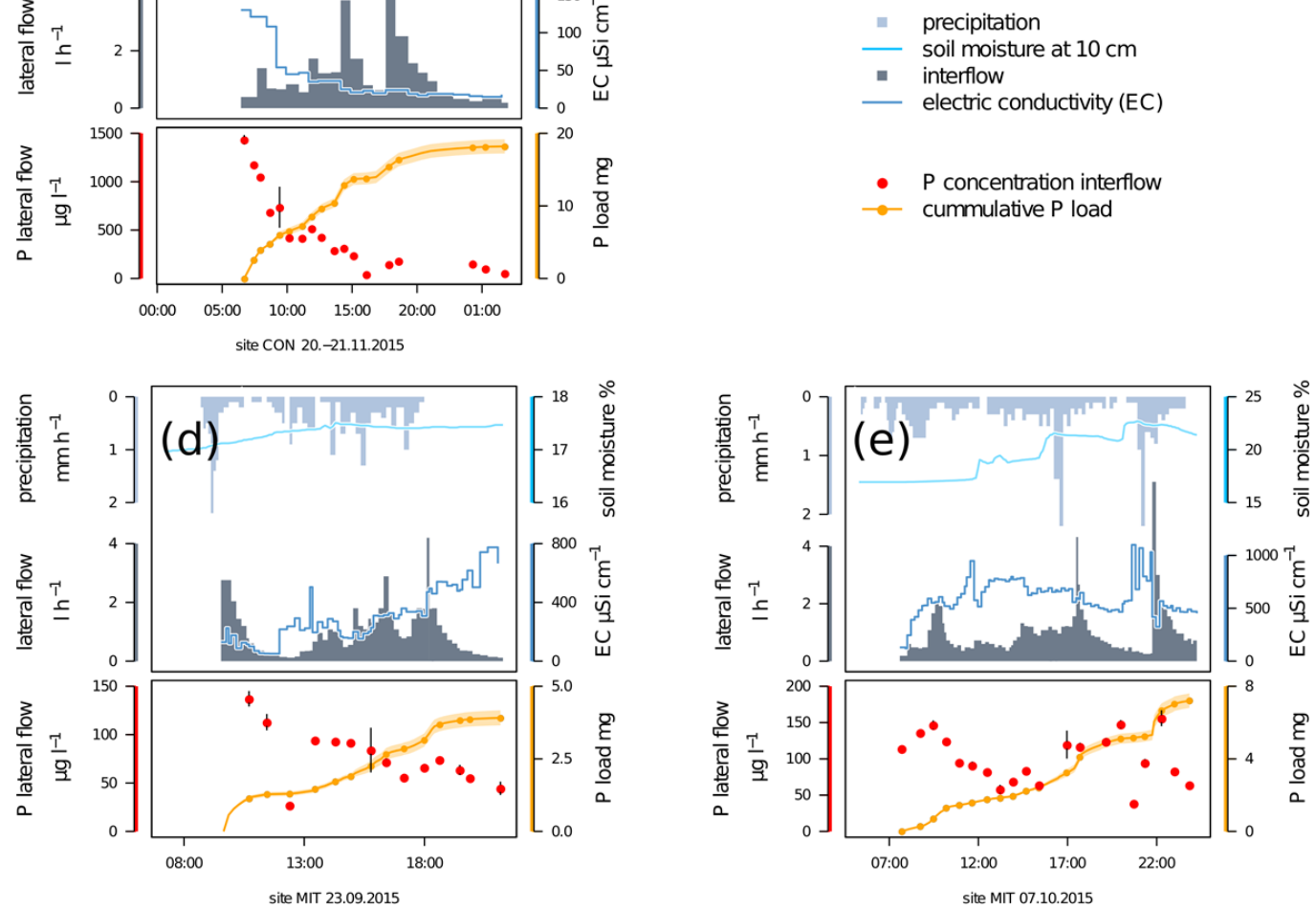

Figure 2 Hydrological conditions and P transport during exemplary lateral flow events at the sites CON (a), MIT (b, c) and VES $(d, e)$. Individual sample measurement uncertainty for $P_{\text {tot }}$ is given as black bar, cumulative uncertainty for $P_{\text {tot }}$ load as orange area behind the respective symbols. 
SOIL Discuss., https://doi.org/10.5194/soil-2018-13

Manuscript under review for journal SOIL

Discussion started: 4 June 2018

(c) Author(s) 2018. CC BY 4.0 License.

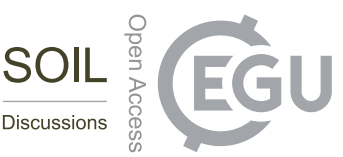

(c) (1)

Page 20
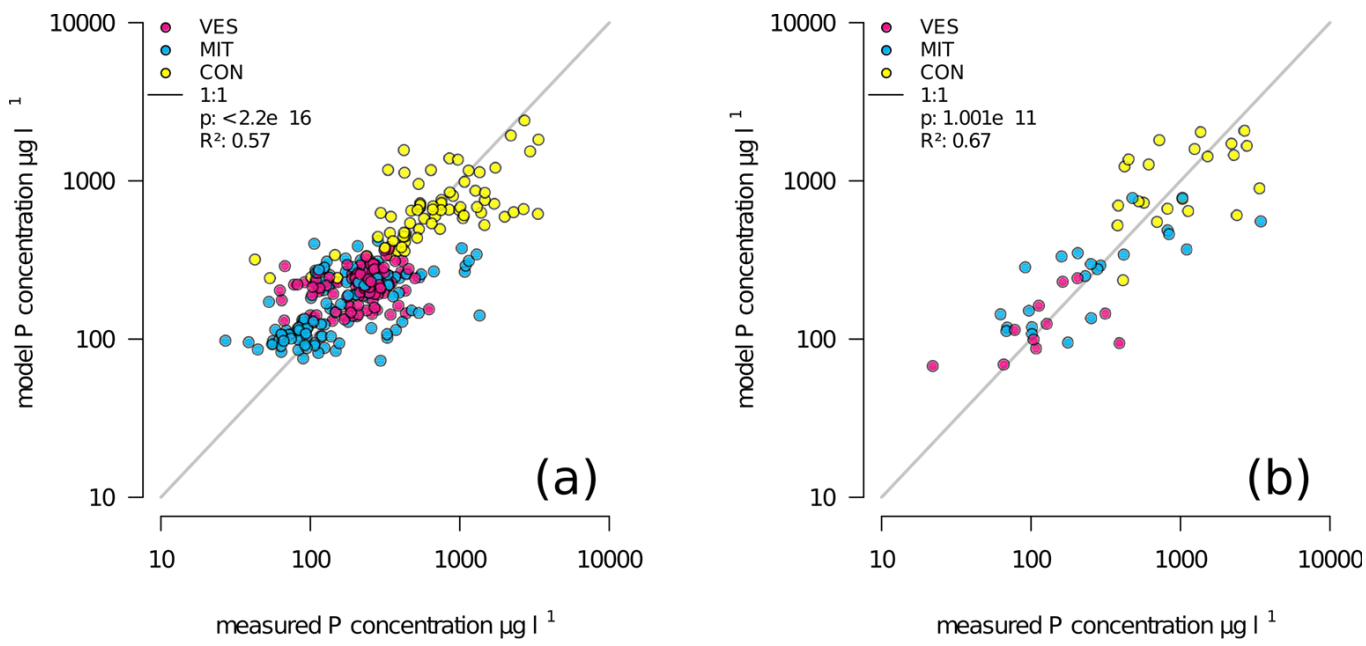

Figure 3 Intra-event data (a) and inter-event data data (b) of the $P_{\text {tot }}$ concentration in lateral flow, and results of the best-fit multiple linear model constructed from our data set. For model parameterization, p-values and explained variability per parameter see Tab. 3. 